\title{
Occupational Stress Among University Lecturers: A Case of Zimbabwe
}

\author{
Sofie Masuku, Stella Muchemwa \\ Solusi University, Bulawayo, Zimbabwe
}

\begin{abstract}
In this modern technological era, employees, especially lecturers, could be expected to enjoy their work primarily due to the convenience of technology. However, stress levels seem to escalate with this technological advancement creating a plethora of unhealthy lifestyles. The result is that one of the setbacks encountered in the present day workplace is increased levels of work-related stress, which contributes to various problems both for the individual employee experiencing stress and for the organization for which one works. This study aimed at exploring stress levels, symptoms, and common stressors for lecturers at a certain Christian university in Zimbabwe. A modified University and College Union model stress questionnaire was distributed to 36 full-time lecturers at the university. The collected data were analyzed using Statistical Package for Social Sciences (SPSS) Version 16 as well as Analysis of Variance (ANOVA). Findings revealed that most of Solusi University lecturers are stressed and others exhausted as indicated by a frequency of $50 \%$. The most common stressors were increased workloads, need to hit targets/deadlines, and long working hours, as indicated by the mean scores of 2.6667, 2.6250, and 2.9167 respectively. Lecturers were heterogeneous in their response with regard to increased workloads, as shown by a standard deviation of 1.00722. Finally, there was no significant difference in responses when it comes to gender, age, faculty, as well as workload.
\end{abstract}

Keywords: occupational stress, stress symptoms, stressors, exhaustion

\section{Introduction}

Lecturing is a profession that is highly valued in Zimbabwe, if not in the world, however, instead of enjoying their work, lecturers have been impacted with stress. In simpler terms, stress can be defined as any outside force or event that has an effect on our body/mind. Russel (2000a) defined it as an excess of demand made upon the adaptive capabilities of the mind and body and is seen in the form of physical demand, mental demand, or both. This means that, without stress, we can hardly do anything since any performance is triggered by some level of stress. Stress therefore is essential in our lives, however, it should be noted that while stress is necessary and positive, it can also be negative and harmful. Stress can be harmful when the stressor increases and comes to a point when the body and mind are so overwhelmed with tension that they can no longer copy.

The Healthline (2010) editorial team came up with three categories of stress being personal which includes relationships, emotional problems, life changes, and money. The next category is social and this includes 
beliefs, environment, occupation, and discrimination in gender, race, or ethnicity. The last category discussed was traumatic events.

\section{Literature Review}

Occupational stress among lecturers has attracted a number of researchers in order to find out mainly causes, vulnerability, effect, and management of stress. Moore (2001) found out that lecturers are stressed especially those who have high expectations and want to achieve their job goals. Matt (2002) propounded that teacher stress is a real phenomenon and that high levels are associated with a combination of causal factors like those intrinsic to teaching, individual vulnerability, and organizational influences. Vance, Humphreys, and Reynold (1989) argued that the work lecturers are asked to do, for example, dealing with students disputes, time tabling, and other lecturing-related activities, is considered to be low value yet it adds to lecturer overload and eventually stress.

In the introduction of his book, Stress Free Teaching, Russel (2000b) wrote of a Mrs. Benson, an English high school teacher who was awarded 47,000 pounds in 1999 from her employer, Ministry of Education, with the help of the National Union of Teachers. Her main claim was that she worked in excess of 60 hours each week and it was this that made her ill.

More researches reveal the dangers of job-related stress among lecturers. Seaward (2004) argued that stress is the greatest threat of our time to humans. Recent World Health Organization (WHO) surveys on stress and illness came to the conclusion that stress is hitting a fever pitch in every nation; so alarmed were the surveyors by the results that they cited stress as a "global epidemic".

Although one can argue that challenges are good and can help a worker prove himself/herself by accomplishing the task, unfortunately, some challenges may be beyond the capacity and expertise of the employees to the extent that they become harmful. An example is when physical and emotional responses to job requirement do not match the abilities, resources, and needs of the worker. Job stress can lead to poor health (mentally and physically) or even injury. Smith (2010) exposed that according to Northwest National Life Insurance Company, $25 \%$ of Americans view their jobs as number one stressor in their lives; $75 \%$ believe that there are currently more workers affected by on-the-job stress than a generation ago. Harris (2007) highlighted that $28 \%$ of U.S. employees reported that they have been so stressed at work in the last year that they have yelled or screamed on the job, and $20 \%$ have been driven to tears.

Gibbons (1998) carried out a study in England and Ireland on stress levels among lecturers and discovered that among his sample, 70\% lecturers in Ireland and 57.5\% lectures in England suffered from work-related stress mainly due to high workloads, i.e., 20.6 hours and 22 hours for Ireland and England respectively.

Borg and Riding (2013) carried out a questionnaire survey of 545 teachers in Maltese secondary schools. Some of the demographic characteristics of their sample were related to self-reported teacher stress, job satisfaction, and career commitment. Results showed that teachers who reported greater stress were less satisfied with teaching, reported greater frequency of absences and a greater number of total days absent, and were more likely to leave teaching (career intention) and less likely to take up a teaching career again (career commitment).

Some research was also done on school teachers. Kikknos (2007) researched on job stress among primary school teachers and found out that emotional exhaustion and depersonalization were related to working environmental stressors. 
It can be said that that it is not enough to realize that lecturers are stressed; a remedy need to be found. On this note, Thomas and Lankau (2009) in their research found out that work place social support minimized emotional exhaustion. Additionally, Salami (2011) researched among college education lecturers in Uganda and his research findings imply that interventions designed to improve lecturers' classroom management skills, social network, and assessment of their personality traits reduce stress among lecturers.

When considering the above reviews, the researchers have realized that the issues of stress are real and of great concern that need immediate attention in their different contexts.

\section{Occupational or Work-Related Stress}

In this study, we will look at occupational stress as one example of negative stress and due to research, there is a growing understanding that job-related stress negatively affects the health of workers (Sauter et al., 1999; Weir, 2013; Martin, 2013). Researchers on occupational stress define stress as a physical, mental, or emotional response to events that causes bodily or mental tension. WHO (n.d.) defined occupational or work-related stress as the response workers may have when presented with work demands and pressures that are not matched to their knowledge and abilities and which challenge their ability to cope. Stress manifests itself in a number of physical, emotional, and mental ways. This condition is usually referred to as burnout (Scott, 2012).

Symptoms of burnout among workers vary but they include all or some of the following: absenteeism from work, depression, eating disorders, pains whose sources cannot be located, fainting, impatience, headaches, and lack of concentration (Fowler, 2011; Gerry, 2013). On a similar note, Hammer (2013) argued that research evidence indicated that work-life stress serves as a negative occupational exposure relating to poor health behaviors, including smoking, poor food choices, low levels of exercise, and decreased sleep time.

When considering teachers and lecturers in the education circles, there are boundaries that surround education and these are stress sources. Russel (2000a) proposed the following as stress sources: students, parents, employers, education managers, government, administrators, assessors, and inspectors. The above parties are education-interested parties and they want the best for students. Most of the time, all student failure is heaped on the instructor ignoring other factors, especially the failure by those responsible to provide the needed resources and support.

\section{Universities in Zimbabwe}

At her political independence in 1980, Zimbabwe had one university, that is, the University of Zimbabwe. Till the early 1990s, it was the only university in the country, however, it could not stand the pressure of students, thus both government and private universities were permitted to operate so as to relieve the situation. Among the private universities, Africa University, a chartered university of the Methodist church was granted a Charter in in 1991 followed by Solusi University, a chartered university of the Seventh Day Adventist Church, in 1992. Solusi University, located 50 kilometers west of Bulawayo, Zimbabwe, is a co-educational institution which was founded in 1894 as one of the first of the hundreds of Seventh Day Adventist mission stations. It was named after Chief Soluswe, near whose home the Mission was founded (UniversityParadise ${ }^{\mathrm{TM}}, 2011$ ). After these, many more (both private and government) universities were established in the country; today, there are 16 universities in Zimbabwe.

The university in question has a divine philosophy; it believes that human beings were created by God in 
His own image and that, through sin, they became separated from God (Eastchance.com, 2013). However, through the redemptive work of Jesus Christ, humans can be restored to a full relationship with God. In keeping with these beliefs, the university gives special emphasis to the development of the individual's spiritual, mental, physical, and social faculties. When considering this philosophy, one can picture a stress-free environment for both students and lecturers.

Work-related stress and resulting sickness absence have cost institutions and countries a fortune, for example, the U.K. economy uses about $£ 3.7$ billion every year (Stranks, 2005). The researchers want to find out if this is applicable to a church institution which values humanity so much.

\section{Statement of the Problem}

Lecturing is a profession that is highly valued in Zimbabwe, if not in the world. However, like any other workers elsewhere, these lecturers are affected by stress and when it overcomes them, they can hardly execute their duties. This study wants to find out if this situation is also true to Solusi University, a church-related institution.

\section{Research Questions}

Three research questions guided this study:

1. What are the stress symptoms experienced by lecturers at Solusi University?

2. Which are the most common factors (stressors) that cause job stress to Solusi University lecturers?

3. Are there any significant differences in terms of occupational stress symptoms and common stressors experienced by different sub-groups of the demographic factors, that is, position, gender, age, faculty, and workload?

\section{Significance of the Study}

The study will be useful to decision-makers of Solusi University and other tertiary institutions in the country, who, based on the findings of the study, can use the findings as bases for policies for retention of lecturers and also for stress management techniques.

\section{Methods}

\section{Sample of the Study}

The population of the study was all the 36 full-time lecturers in the different faculties of Solusi University.

\section{Instrumentation}

Data were collected using lecturers' questionnaire modified from University and College Union model stress questionnaire (https://www.ucu.org.uk/media/docs/i/s/stresstool_question.doc). The questionnaire was distributed to all the 36 full-time lecturers, but only 24 lecturers $(67 \%)$ returned the research questionnaire.

\section{Data Collection}

Questionnaires were distributed to each lecturer and time was given for them to fill it in and the research assistant would go back to pick up the questionnaire. Sometimes, the lecturers would not have filled in the questionnaire and extra time was given to them.

\section{Data Analysis}

Data were analyzed using Statistical Package for Social Sciences (SPSS) Version 16. Frequencies 
and descriptive statistics were used to analyze the data. Analysis of Variance (ANOVA) was used for question 3.

\section{Findings}

The respondents were 12 males and 11 females and one failed to respond to the gender question. The majority (15) of the respondents were between the ages of 36 and 55. Five of the lecturers that responded were between 26 and 35 years and four were 56 years and above. Those who responded were three from the Faculty of Education, two from the Faculty of Art, seven from the Faculty of Business, nine from the Faculty of Sciences, and three indicated other. On the number of hours worked each week, four indicated that they worked between 30 and 35 hours, five worked between 36 and 40 hours, three worked between 41 and 45 hours, five worked between 46 and 50 hours, and five worked 51 plus hours.

\section{Research Question 1: What Are the Stress Symptoms Experienced by Lecturers at Solusi University?}

According to Table 1, the majority of the lecturers never had skin rashes, asthma, or heart disease, as indicated by the percentages of 70.8, 83.3, and 83.3 respectively. Some of the lecturers sometimes had headaches or migraines, aches and pains, poor sleep patterns, indigestion, anxiety, depression, inability to concentrate, and erratic moods, as indicated by the percentages of 67.7, 50.0, 41.7, 45.8, 50.0, 50.0, 62.5, and 50.0 respectively. It is apparent that there were some lecturers who were often exhausted, as indicated by a frequency of $50.0 \%$. Some of the lecturers often had aches and pain, poor sleep patterns, changes in appetite, and inability to concentrate, as indicated by the percentages of $29.2,20.8,16.7$, and 16.7 respectively.

Table 1

Stress Symptoms

\begin{tabular}{lllc}
\hline & Never (\%) & Sometimes (\%) & Often (\%) \\
\hline Headaches/migraine & 25 & 66.7 & 4.2 \\
Aches and pain & 12.5 & 50 & 29.2 \\
High blood pressure & 50 & 33.3 & 8.3 \\
Poor sleep patterns & 33.3 & 41.7 & 20.8 \\
Skin rashes & 70.8 & 20.8 & 0 \\
Indigestion & 41.7 & 45.8 & 8.3 \\
Asthma & 83.3 & 12.5 & 0 \\
Anxiety & 33.3 & 50 & 12.5 \\
Depression & 37.5 & 50 & 8.3 \\
Heart disease & 83.3 & 8.3 & 0 \\
Changes in appetite & 37.5 & 37.5 & 16.7 \\
Exhaustion & 12.5 & 33.3 & 50 \\
Inability to concentrate & 16.7 & 62.5 & 16.7 \\
Erratic moods & 33.3 & 50 & 12.5 \\
Low self-esteem/confidence & 45.8 & 37.5 & 12.5 \\
\hline
\end{tabular}

Research Question 2: Which Are the Most Common Factors (Stressors) That Cause Job Stress to Lecturers?

In this question, anything with a mean of 2.5 and above was considered as the most common stressor. Table 2 shows the most common stressors to be the increased workloads, the need to hit targets/deadlines, and long working hours, as indicated by the mean scores of $2.6667,2.6250$, and 2.9167 respectively. These findings 
concur with those by Gibbons (1998), who discovered that 70\% of lecturers in Ireland and $57.5 \%$ of lecturers in England were stressed due to high workloads. Again, Moore (2001) and Borg and Rinding (2013) realized in their studies that lecturers, especially those with high expectations and want to achieve job goals, were stressed most.

Table 2

Demands

\begin{tabular}{llll}
\hline & $N$ & $M$ & $S D$ \\
\hline 8a. Dealing with student discipline & 24 & 1.6250 & 1.01350 \\
8b. Larger classes/more students & 24 & 2.3750 & 1.17260 \\
8c. Dealing with aggressive/violent behavior & 24 & 1.7917 & 1.14129 \\
8d. Teaching new courses & 24 & 2.0417 & 1.12208 \\
8e. Dealing with new education initiatives & 24 & 2.1667 & 0.86811 \\
8f. Administration & 24 & 2.3333 & 1.20386 \\
8g. Frequent changes to timetable & 24 & 2.0417 & 1.04170 \\
8h. Increased workloads & 24 & 2.6667 & 1.00722 \\
8i. Need to hit targets/deadlines & 24 & 2.6250 & 0.96965 \\
8j. Long working hours & 24 & 2.9167 & 0.88055 \\
8k. Increase in temporary/ part time contracts & 24 & 1.9167 & 0.92861 \\
81. Inspection/auditing processes & 23 & 1.6522 & 0.83168 \\
8m. Lone working & 23 & 1.7826 & 1.08530 \\
8n. Off-site/multi-site working & 24 & 1.5833 & 0.97431 \\
8o. Travelling time & 24 & 1.5833 & 0.82970 \\
8p. Lack of regular breaks & 24 & 2.3750 & 1.13492 \\
8q. Staff appraisal & 24 & 1.5833 & 0.82970 \\
Experience & 19 & 1.6447 & 0.31461 \\
Valid $N$ (listwise) & 18 & - & - \\
\hline
\end{tabular}

The Solusi lecturers were homogeneous in their responses with regard to the need to hit targets/deadlines and working long hours with standard deviations of 0.96965 and 0.88055 respectively. They were also heterogeneous in their responses with regard to increased workloads, as shown by the standard deviation of 1.00722 .

Table 3 shows the factors related to control. The lecturers indicated that changes in terms and conditions without consultation was a stressor to them, as indicated by a mean of 2.7391 , but they were not in total agreement, as indicated by the standard deviation of 1.13688. Lack of funds and support to do the job, giving of responsibility without the authority to take decisions, and insufficient time for scholarship and/or research also proved to be stressors to the respondents, as indicated by the mean scores of 3.0435, 2.6087, and 3.1739 respectively. The standard deviations of 1.18622 and 1.11759 on lack of funds and responsibility without authority respectively indicate that the respondents were not in agreement with these stressors, but the standard deviation of 0.98406 on insufficient time for scholarship and research show that they were in agreement with their responses.

When it comes to relationships, Table 4 shows that there was little harassment by managers, staff, or students, as indicated by a mean of 1.6667 , and the respondents were in agreement as seen by the standard deviation of 0.91683 . The respondents felt that their work was not valued, as indicated by a mean of 2.5833. The standard deviation of 1.13890 showed that the respondents were not in total agreement in their responses. 
The respondents were asked about their job description. They still felt that the efforts they put in their work was not valued as indicated by a mean of 2.5833 and standard deviation of 1.24819 , which meant that they were not quite in agreement with this statement. Unclear job description showed a mean of 2.2500, which was not that much of a problem. They did not have conflicting demands in job role as indicated by a mean of 1.8636, and the standard deviation of 0.99021 indicates that they are in agreement with this statement (see Table 5).

Table 3

Control

\begin{tabular}{llll}
\hline & $N$ & $M$ & $S D$ \\
\hline 9a. Not able to exert control over demands made & 23 & 1.9130 & 0.90015 \\
9b. Lack of participation in decision making & 23 & 2.4783 & 1.16266 \\
9c. Dealing with competing demands - unable to plan working day & 22 & 2.1364 & 1.03719 \\
9d. Work linked to deadlines and targets & 23 & 2.2609 & 1.09617 \\
9e. Changes in terms and conditions without consultation & 23 & 2.7391 & 1.13688 \\
9f. Job changes without consultation & 23 & 2.1304 & 1.17954 \\
9g. Lack of funds and support to do the job & 23 & 3.0435 & 1.18622 \\
9h. Given responsibility without the authority to take decisions & 23 & 2.6087 & 1.11759 \\
9i. Insufficient time for scholarship and/or research & 23 & 3.1739 & 0.98406 \\
Control & 22 & 2.4899 & 0.79657 \\
Valid $N$ (listwise) & 22 & - & - \\
\hline
\end{tabular}

Table 4

Relationships

\begin{tabular}{llll}
\hline & $N$ & $M$ & $S D$ \\
\hline 10a. Bullying behavior from managers/staff/students & 23 & 2.0870 & 1.08347 \\
10b. Harassment by managers/staff/students & 24 & 1.6667 & 0.91683 \\
10c. Dealing with fluctuating situations & 24 & 2.1667 & 1.04950 \\
10d. Lack of line management support & 24 & 2.2917 & 1.08264 \\
10e. Feeling isolated in curriculum area & 24 & 1.9583 & 1.08264 \\
10f. Lack of communication with staff & 24 & 2.3750 & 1.13492 \\
10g. New styles of institutional management & 24 & 2.2917 & 1.08264 \\
10h. Feeling that your work is not valued & 24 & 2.5833 & 1.13890 \\
10i. Lack of involvement and information as hourly paid lecturer & 24 & 2.4583 & 1.17877 \\
Relationships & 23 & 2.2271 & 0.80436 \\
Valid $N$ (listwise) & 23 & - & - \\
\hline
\end{tabular}

Table 5

Job Description

\begin{tabular}{llll}
\hline & $N$ & $M$ & $S D$ \\
\hline 11a. Conflicting demands in job role & 22 & 1.8636 & 0.99021 \\
11b. Unclear job description & 24 & 2.2500 & 1.22474 \\
11c. Lack of support in job role & 23 & 2.2174 & 1.16605 \\
11d. Efforts not valued & 24 & 2.5833 & 1.24819 \\
Role & 22 & 2.1705 & 0.96173 \\
Valid $N$ (listwise) & 22 & - & - \\
\hline
\end{tabular}




\section{Research Question 3: Are There Any Significant Differences in Terms of Occupational Stress Symptoms and Common Stressors Experienced by Different Sub-groups of the Demographic Factors, That Is, Position, Gender, Age, Faculty, and Workload?}

There was no significant difference in responses when it comes to gender, age, faculty, as well as workload. This means that different sub-groups of the respondents were affected by stress in the same manner and they aslo displayed the same stress symptoms.

\section{Conclusion}

Research findings revealed that most of the lecturers at the Christian university in question were stressed. Some of them were even exhausted as indicated by a frequency of $50 \%$. Among the stressors, the most common ones were increased workloads, need to hit targets/deadlines, and long working hours, as indicated by the mean scores of 2.6667, 2.6250 and 2.9167 respectively. Working hours for some lecturers were extremely high, that is, more than 51 hours per week. This was mainly caused by increased workloads mainly due to university operation expansion. Statistical analysis also revealed that lecturers were heterogeneous in their responses with regard to increased workloads, as shown by a standard deviation of 1.00722. Finally, there was no significant difference in responses when it comes to gender, age, faculty, as well as workload, hence, these were not factors affecting stress among those university lecturers; all lecturers were negatively affected.

Based on these findings, it can be concluded that since lecturers at the Christian university are stressed, those from non-Christain universities in Zimbabwe are stressed as well. The study, therefore, recommends that universities should employ adequate lecturers for the smooth running of their programs as well as for the good welfare of the lecturers.

\section{References}

Borg, M. G., \& Riding, R. J. (2013). Occupational stress and satisfaction in teaching. Retrieved October 2, 2013, from http:/onlinelibrary.wiley.com/doi/10.1080/0141192910170306/abstract

Eastchance.com. (2013). Solusi University. Retrieved July 17, 2013, from http://www.eastchance.com/uni.asp?id=8133

Fowler, J. (2011). 7 signs of job burnout. Retrieved August 7, 2013, from http://www.investopedia.com/financial-edge/0311/7signs-of-job-burnout.aspx

Gerry, L. M. (2013). 10 signs you're burning out and what to do about it. Retrieved October 19, 2013, from http://www.forbes. com/sites/learnvest/2013/04/01/10-signs-youre-burning-out-and-what-to-do-about-it

Gibbons, C. (1998). An investigation into the effects of organisational change on occupational stress in further education lecturers. Journal of Further and Higher Eduction, 22(3), 315-328.

Hammer, L. B. (2013). Total worker health and work-life stress. Retrieved from http://journals.lww.com/joem/Fulltext/2013/12 001/Total_Worker_Health_and_Work_Life_Stress.5.aspx

Harris, I. (2007). 13th annual "Attitudes in the American Workplace" poll conducted by Harris Interactive for the Marlin Company. Retrieved September 7, 2013, from http://www.prweb.com/releases/2007/10/prweb558259.htm

Healthline. (2010). Causes of stress. Retrieved May 27, 2014, from http://www.healthline.com/health/stress-causes\#1

Kikknos, C. M. (2007). Job stress, personality and burnout in primary school teachers. British Journal of Educational Psychology, $77(1), 229-243$.

Martin, J. (2013). Work stress directly linked to heart disease, again. Work in progress. Retrieved from http://www.forbes.com /sites/work-in-progress/2013/04/25/work-stress-directly-linked-to-heart-disease-again/

Matt, J. (2002). Teacher stress: A critical view of recent findings and suggestions for future research directions. Stress News, 14(1), 136-147. 
Moore, K. (2001). Hospital restructuring: Impact on nurses mediated by social support and a percentage of challenge. Journal of Health and Human Services Administration, 23(4), 490-516.

Russel, J. (2000a). Teacher stress. Retrieved October 7, 2013, from http://www.cedu.niu.edu/ shumow/itt/teacher\%2520stress. pdf

Russel, J. (2000b). Stress free teaching. Retrieved October 6, 2013, from http://books.google.com/books/about/Stress_Free_ Teaching. html\%3Fid\%3Dpk09AAAAIAAJ

Salami, S. O. (2011). Job stress and burnout among lecturers: Personality and social support as moderators. Asian Social Science, 7(5), 110-121. Retrieved October 7, 2013, from http://www.ccsenet.org/ass

Sauter, S., Murphy, L., Colligan, M., Swanson, N., Hurrell, J. Jr., Scharf, F. Jr., \& Tisdale, J. (1999). Stress at work (DHHS Publication No. 99-101, National Institute for Occupational Safety and Health working group). Retrieved from http://www.cdc.gov/niosh/docs/99-101/

Scott, E. (2012). Stress and burnout: Burnout symptoms and causes: The origins of burnout. Retrieved from http://stress.about. com/od/burnout/a/stressn_burnout.htm

Seaward, B. C. (2004). Managing stress and strategies for health and wellbeing. Boston, M.A.: Jones and Bartlett Publishers.

Smith, B. (2010). Is job stress eroding your health. Retrieved June 25, 2013, from http://www.sooperarticles.com/health-fitnessarticles

Solusi University Website. (2013). Faculties. Retrieved July 11, 2013, from http://solusi.ac.zw/?page_id=23

Stranks, J. (2005). Stress at work. Retrieved September 22, 2013, from http://www.psypress.com/books/details/978075066542

Thomas, C. H., \& Lankau, M. N. (2009). Preventing burnout: The effects of LMX and mentoring of socialization, role stress, and burnout. Human resource management, 48(3), 417-432. Retrieved July 11, 2013, from http:// www.academia.edu/.../Trust

UniversityParadise ${ }^{\mathrm{TM}}$. (2011). Solusi University. Retrieved July 17, 2013, from http://www.universityparadise.com/solusi-uni versity/

Vance, B., Humphreys, S., \& Reynold, F. (1989). Sources and manifestation of occupationalsources and manifestation of occupational stress as reported by fulltime teachers working in a bia school. Retrieved December 2, 2014, from http://jaie.asu.edu/v28/v28s2sou.htm

Weir, K. (2013, September). Work, stress and health: Research from the 10th International Conference on Occupational Stress and Health focuses on ways to reduce stress and improve worker health. Monitor on Psychology, 44(8), 40. Retrieved from https://www.apa.org/monitor/2013/09/stress-health.aspx

World Health Organization (WHO). (2002). A seminar universal health coverage. Retrieved September 2, 2013, from $\mathrm{http} / / /$ www.paho.org/hq/index.php?view=details\&id=23\%3ASeminar+No.1\%3A+Universal+Health+Coverage+and+Social+ Security $\% 3 \mathrm{~A}+$ towards + Integration + of + Health + Systems\&option $=$ com

WHO. (n.d.). Stress in the work place: Some simple questions and answers. Retrieved May 15, 2014, from http://www.who.int/ occupational_health/topics/stressatwp/en/ 